\title{
PENGERTIAN SUPERVISI PENDIDIKAN
}

\author{
NAMA : LEONALDI \\ NIM :0142S1A018027
}

\begin{abstract}
Abstrak
Supervisi merupakan pembinaan yang di berikan kepada seluruh staf sekolah termasuk guru, kepala sekolah dan sebagainya dalam maksud perbaikan agar mereka dapat meningkatkan kemampuan untuk mengembangkan situasi atau proses pembelajaran yang baik. Jadi yang menjadi sasaran supervisi tersebut adalah guru.

Tujuan supervisi tersebut tidak lain untukmengembangkan dan meningkatkan proses belajar mengajar agar menjadi lebih baik . sehingga tujuan pendidikan indonesia bisa tercapai dengan maksimal.
\end{abstract}

\section{A. Tujuan Pembelajaran}

Mahasiswa mampu menganalisa pengertian supervisi pendidikan

\section{B. Pengertian Supervisi Pendidikan}

\section{Pengertian Supervisi}

Istilah supervisi berasal dari bahasa inggris yang berarti pengawasan. Sedangkan jika dilihat dari bentuknya supervisi berasal dari dua kata yaitu super dan visi. Super berarti atas, lebih dan visi berarti lihat, tilik, awasi. Jadi supervisi berarti melihat ke atas atau mengawasi bawahan. Secara umum, istilah supervisi berarti mengamati, mengawasi atau membimbing dan menstimulir kegiatankegiatan orang lain dalam maksud perbaikan. Dalam bidang pendidikan, supervisi mengandung konsep umum yang sama namun disesuaikan dengan aktivitasaktivitas pengajaran. 


\section{Pengertian Pendidikan}

Pendidikan (education) secara semantik berasal dari bahasa yunani paidagogia yang berarti pergaulan dengan anak-anak. Pedagogos adalah seorang nelayan atau bujang dalam zaman yunani kuno yang pekerjaannya menjemput dan mengantar anak-anak ke dan dari sekolah. Selain itu, di rumahnya anak tersebut selalu dalam pengawasan dan penjagaan para paedagogos. Istilah ini berasal dari kata paedos yang berarti anak, dan agogos yang berarti saya membimbing atau memimpin.

Menurut Langeveld (1971: 5) pendidikan adalah setiap usaha, pengaruh, perlindungan, dan bantuan yang diberikan kepada anak tertuju kepada pendewasaan anak itu, atau lebih tepat membantu anak agar cukup, cakap melaksanakan tugas hidupnya sendiri. Pengaruh ini datangnya dari orang dewasa (orang yang diciptakan oleh orang dewasa seperti sekolah, buku, putaran hidup sehari-hari dan sebagainya) dan ditujukan kepada orang yang belum dewasa. Dalam perspektif keindonesiaan, pengertian, fungsi, dan tujuan pendidikan dirumuskan dalam Undang-Undang Sistem Modul Manajemen Pendidikan Non Formal 2

Pendidikan Nasional Nomor 20 Tahun 2003 pasal 1 dan 3 "pendidikan adalah usaha sadar dan terencana untuk mewujudkan suasana belajar dan proses pembelajaran agar peserta didik secara aktif mengembangkan potensi dirinya untuk memiliki kekuatan spiritual keagamaan, pengendalian diri, kepribadian, kecerdasaan, dan akhlak mulia, serta keterampilan yang diperlukan dirinya, masyarakat, bangsa dan negara”. Pendidikan nasional berfungsi mengembangkan kemampuan dan membentuk watak serta peradaban bangsa yang bermartabat dalam rangka mencerdaskan kehidupan bangsa, bertujuan untuk berkembangnya potensi peserta didik agar menjadi manusia yang beriman dan bertakwa kepada Tuhan Yang Maha Esa, Berakhlak mulia, sehat, berilmu, cakap, kreatif, mandiri, 
dan menjadi warga negara yang demokratis serta bertanggung jawab (Sulfemi, $2019: 1-2)$.

\section{Tujuan Supervisi Pendidikan}

Tujuan Supervisi Pendidikan adalah perbaikan dan perkembangan proses belajar mengajar secara total. Ini berati tujuan supervisi pendidikan tidak hanya untuk memperbaiki mutu mengajar guru, tetapi juga membina pertumbuhan profesinguru termasuk di dalamnya pengadaan fasilitas yang menunjang kelancaran proses belajar mengajar, peningkatan mutu pengetahuan dan keterampilan guru, pemberian bimbingan dan pembinaan dalam hal implementasi kurikulum, pemilihan dan penggunaan metode mengajar, alat pelajaran, prosedur dan teknik evaluasi pengajaran. Jadi, sekolah yang hendak mewujudkan tujuan dalam belajar sebagaimana yang menjadi fokus pendidikan multikultural haruslah dikelola dengan kepemimpinan kepala sekolah yang kuat. Kepala sekolah tidak hanya sebagai manajer, melainkan lebih dari itu. Ia harus menjadi leader (pemimpin) (Sulfemi, 2019 : 129).

\section{- Secara nasional tujuan konkrit dari supervisi pendidikan adalah :}

1. Membantu guru melihat dengan jelas tujuan-tujuan pendidikan

2. Membantu guru dalam membimbing pengalaman belajar murid.

3. Membantu guru dalam menggunakan alat pelajaran modern.

4. Membantu guru dalam menilai kemajuan murid-murid dan hasil pekerjaan guru

5. Membantu guru dalam menggunakan sumber-sumber pengalaman belajar.

6. Membantu guru dalam memenuhi kebutuhan belajar murid. 
7. Membantu guru dalam membina reaksi mental atau moral kerja guru dalam rangka pertumbuhan pribadi dan jabatan mereka.

8. Membantu guru baru di sekolah sehingga mereka merasa gembira dengan tugasyang diperolehnya.

9. Membantu guru agar lebih mudah mengadakan penyesuaian terhadap masyarakat dan cara-cara menggunakan sumber-sumber yang berasal dari masyarakat.

10. Membantu guru-guru agar waktu dan tenaganya tercurahkan sepenuhnya dalam pembinaan sekolah.

\section{Fungsi Supervisi Pendidikan}

Fungsi supervisi menyangkut bidang kepemimpinan, hubungan kemanusiaan, pembinaan proses kelompok, administrasi personil, dan bidang evaluasi. Pengertian supervisi tersebut, mempertegas bahwa supervisi dilakukan secara intensif kepada guru. Hal ini, secara tidak langsung berdampak pada prestasi belajar siswa. Berpijak pada keterangan ini, maka supervisi pendidikan mempunyai tiga fungsi, yaitu:

1. Sebagai suatu kegiatan untuk meningkatkan mutu pendidikan

2. Sebagai pemicu atau penggerak terjadinya perubahan pada unsur-unsur yan terkait dengan pendidikan

3. Sebagai kegiatan dalam hal memimpin dan membimbing

Secara umum, fungsi dari supervisi pendidikan adalah:

1. Penelitian

2. Penilaian 
3. Perbaikan

4. Peningkatan

Menurut Swearingen (Sahertian, 2008: 21) terdapat 8 fungsi supervisi sebagai berikut:

1. Mengkoordinasi semua usaha sekolah

2. Memperlengkapi kepemimpinan sekolah

3. Memperluas pengalaman guru

4. Menstimukasi usaha-usaha sekolah yang kreatif

5. Memberi fasilitas dan penilaian yang terus menerus

6. Menganalisis situasi belajar mengajar

7. Memberikan pengetahuan dan ketrampilan kepada setiap anggota staf supervisi

8. Memberi wawasan yang lebih luas dan terintegrasi dalam merumuskan tujuantujuan pendidikan dan meningkatkan kemampuan mengajar guru-guru.

\section{E. Prinsip Supervisi Pendidikan}

Menurut Suryo Subroto ada 4 prinsip supervisi pendidikan.

1. Prinsip Ilmiah, memiliki ciri sebagai berikut :

a. Sistematis, dilaksanakan secara teratur, terprogram dan berkelanjutan.

b. Obyektif, berdasarkan pada data informasi.

c. Menggunakan instrumen atau alat yang dapat memberi data. 
2. Prinsip Demokratis Menjunjung tinggi asas musyawarah, memiliki jiwa kekeluargaan yang kuat serta sanggup menerima pendapat orang lain.

3. Prinsip kerja sama Mengembangkan usaha bersama untuk menciptakan situasi belajar mengajar yang lebih baik. Hal ini bisa dilakukan dengan sharing of idea, sharing of experience, memberi motivasi, menstimulasi guru sehingga mereka bisa tumbuh bersama.

4. Prinsip konstruktif dan kreatif Membina inisiatif guru serta mendorongnya untuk aktif dan menciptakan situasi belajar mengajar yang lebih baik. Situasi yang lebih baik maksudnya situasi yang menyenangkan dan tidak menakutkan. Konstruktif maksudnya dapat membangun guru menjadi lebih baik. Kreatif maksudnya adalah hal yang tidak biasa, karena supervisi juga perlu adanya sesuatu yang lain agar tidak terjadi kebosanan diantara guru maupun pengawas.

\section{F. Supervisi Internal Di Manajemen Sekolah}

1. Perencanaan

a. Analisis kebutuhan supervisi internal.

b. Penyusunan program supervisi internal.

c. Penyusunan standar acuan dalam supervisi internal.

2. Pengorganisasian

a. Pembentukan tim pelaksana supervisi internal.

b. Penyusunan jadwal supervisi internal.

3. Pengerahan

a. Pembinaan dan pengarahan kepada tim supervisi internal. 
b.Pelaksanaan supervisi internal.

4. Pengawasan

a. Pemantauan kegiatan supervisi internal.

b. Pelporan supervisi internal.

c. Evaluasi supervisi internal. (Sulfemi, 2019 :16)

\section{G. Kesimpulan}

Supervisi merupakan pembinaan yang diberikan kepada seluruh staf sekolah agar mereka dapat meningkatkan kemampuan untuk mengembangkan situasi pembelajaran yang baik. Orang yang menguji supervisi yaitu supervisior. Sasaran pembinaan supervisi bisa untuk kepala sekolah, guru, dan pegawai tata usaha.

Tujuan supervisi yaitu untuk meningkatkan situasi belajar mengajar yang lebih baik melalui pembinaan dengan meningkatkan proses pembelajaran dan profesi mengajar. Fungsi dan tujuannya yaitu sebagai arah pendidikan, tujuan pendidikan agar dapat tercapai. Oleh karena itu supervisi memiliki manfaat yaitu untuk mengkoordinasi semua usaha yang ada disekolah agar berjalan dengan lancar. 


\section{LATIHAN SOAL}

\section{Pilihan Ganda}

1. Supervisi berasal ddari dua kata yaitu super dan visi. Super berarti atas, lebih dan visi berarti liaht, ilik, awasi. Jadi supervisi berarti melihat keatas atau mengawasi kebawah. Berasal dari bahasa apakah supervisi ?
a. Jepang
d. Yunani
b. Jerman
e. Inggris
c. Kanada

2. Pendidikan berasal dari bahasa Yunani yaitu paidagogia yang artinya ..
a. Pergaulan dengan anak-anak
d. Pergaulan bebas
b. Pergaulan dengan orang dewasa
e. Pergaulan jalanan
c. Pergaulan dengan perempuan

3. Ada berapakah fungsi supervisi menurut Swearingen ?
a. 4
d. 7
b. 3
e. 8
c. 5

4. Apa saja prinsip supervisi pendidikan menuru Suryo Subroto ?
a. ilmiah, demonstrasi, kerjasama, prinsip konstruktif dan kreatif
b. ilmiah, demonstrasi, kerjasama, organisasi
c. kimia, demonstrasi, kerjasama, prinsip konstruktif dan kreatif
d. ilmiah, media, kerjasama, prinsip konstruktif dan kreatif
e. ilmiah, demonstrasi, efektif, prinsip konstruktif dan kreatif

5. Fungsi umum dari supervisi pendidikan adalah.
a. penelitian, pemaparan, penilaian, pembahasan
b. penelitian, penilaian, perbaikan, peningkatan
c. penelitian, pencapaian, penghargaan, pengamanan
d. penelitian, pemaparan, penyampaian, pengamanan
e. penelitian, penggabungan, pembinaan, pemaparan 
6. Ada berapa tujuan supervisi pendidikan secara nasional ??
a. 4
d. 6
b. 5
e. 10
c. 8

7. Fungsi supervisi menyangkut bidang apa?

a.kepemimpinan, hubungan kemanusiaan, pembinaan proses kelompok, administrasi personil, dan bidang eksekusi

b.kepemimpinan, hubungan kemanusiaan, pembinaan proses kelompok, administrasi personil, dan bidang evaluasi

c.kepemimpinan, hubungan kemanusiaan, pembinaan proses kelompok, manajemen personil, dan bidang evaluasi

d.pengelompokan, hubungan kemanusiaan, pembinaan proses kelompok, administrasi personil, dan bidang evaluasi

e.kepemimpinan, hubungan kemasyarakatan, pembinaan proses kelompok, administrasi personil, dan bidang evaluasi

8. Di dalam supervisi terdapat prinsip ilmiah. Sebutkan ciri prinsip ilmiah ?
a. Sistematis
d. proyektif
b. afektif
e. administratif
c. kognitif

9. "Pendidikan adalah usaha sadar dan terencana untuk mewujudkan suasana belajar dan proses pembelajaran agar peserta didik secara aktif mengembangkan potensi dirinya untuk memiliki kekuatan spiritual keagamaan, pengendalian diri, kepribadian, kecerdasaan, dan akhlak mulia, serta keterampilan yang diperlukan dirinya, masyarakat, bangsa dan negara". Pengertian diatas oleh ...
a. Pendidikan Nasional Nomor 20 Tahun 2003 pasal 1 dan 3
b. Pendidikan Nasional Nomor 20 Tahun 2004 pasal 1 dan 3
c. Pendidikan Nasional Nomor 20 Tahun 2005 pasal 1 dan 3
d. Pendidikan Nasional Nomor 20 Tahun 2006 pasal 1 dan 3
e. Pendidikan Nasional Nomor 20 Tahun 2007 pasal 1 dan 3 
10. Di dalam supervisi internal manajemen sekolah terdapat pengawasan. Sebutkan fungsinya?

a. Analisis kebutuhan, penyusunan program, penyusunan standar acuan

b. Analisis kebutuhan, penyusunan program, penyusunan standar nsional

c. Analisis kebutuhan, penyusunan kegiatan, penyusunan standar acuan

d. Analisis keinginan, penyusunan kegiatan, penyusunan standar acuan

e. Analisis keinginan, penyusunan kegiatan, penyusunan standar nasional

\section{Essay}

1. Jelaskan pengertian supervisi secara umum?

2. Jelaskan tujuan dari supervisi?

3. Sebutkan 3 fungsi supervisi pendidikan?

4. Sebutkan prinsip supervisi menurut Suryo Subroto?

5. Menurut anda apakah supervisi itu penting dalam pendidikan! 


\section{KUNCI JAWABAN}

\section{Pilihan Ganda}

1. $\mathbf{E}$

2. A

3. $\mathrm{E}$

4. A

5. B
6. $\mathbf{E}$

7. B

8. A

9. A

10. C

\section{Essay}

1. Secara umum, istilah supervisi berarti mengamati, mengawasi atau membimbing dan menstimulir kegiatan-kegiatan orang lain dalam maksud perbaikan. Dalam bidang pendidikan, supervisi mengandung konsep umum yang sama namun disesuaikan dengan aktivitas-aktivitas pengajaran.

2. Tujuan Supervisi Pendidikan adalah perbaikan dan perkembangan proses belajar mengajar secara total. Ini berati tujuan supervisi pendidikan tidak hanya untuk memperbaiki mutu mengajar guru, tetapi juga membina pertumbuhan profesinguru termasuk di dalamnya pengadaan fasilitas yang menunjang kelancaran proses belajar mengajar, peningkatan mutu pengetahuan dan keterampilan guru, pemberian bimbingan dan pembinaan dalam hal implementasi kurikulum, pemilihan dan penggunaan metode mengajar, alat pelajaran, prosedur dan teknik evaluasi pengajaran

3. supervisi pendidikan mempunyai tiga fungsi, yaitu:

a. Sebagai suatu kegiatan untuk meningkatkan mutu pendidikan 
b. Sebagai pemicu atau penggerak terjadinya perubahan pada unsur-unsur yan terkait dengan pendidikan

c. Sebagai kegiatan dalam hal memimpin dan membimbing

4. Menurut Suryo Subroto terdapat empat prinsip supervisi pendidikan, yaitu prinsip ilmiah, demonstrasi, kerjasama dan prinsip konstruktif dan kreatif.

5. Supervisi merupakan pembinaan yang diberikan kepada seluruh staf sekolah agar mereka dapat meningkatkan kemampuan untuk mengembangkan situasi pembelajaran yang baik. Orang yang menguji supervisi yaitu supervisior. Sasaran pembinaan supervisi bisa untuk kepala sekolah, guru, dan pegawai tata usaha. Disini kita bisa lihat bahwa supervisi itu sangat penting bagi dunia pendidikan karena didalam supervisi itu bukan hanya mengawasi mengamati melainkan juga membina proses belajar mengajar sehingga tujuan dari pembelajaran tersebut bisa tercapai dan tujuan pendidikan indonesia bisa ikut tercapai. 


\section{DAFTAR PUSTAKA}

Sulfemi, Wahyu Bagja.(2019).Manajemen Sekolah.

Sulfemi, Wahyu Bagja. (2018). Modul Manajemen Pendidikan Non Formal. Bogor:

STKIP Muhammadiyah Bogor.

Sulfemi, W. B. (2019). Manajemen Pendidikan Berbasis Multi Budaya. Bogor : STKIP Muhammadiyah Bogor.

http://eprints.walisongo.ac.id/7041/3/BAB\%20II.pdf

Swearingen(Sahertian, 2008: 21). 8 Fungsi Supervisi

Suryo Subroto. Prinsip Supervisi Pendidikan

https://ahmadwahyumaruto.blogspot.com/2016/05/supervisi-pendidikan.html

https://www.asikbelajar.com/tujuan-supervisi-pendidikan/

http://kanguut.blogspot.com/2012/04/fungsi-supervisi-pendidikan.html 